\title{
Assessment of the Competitiveness of the Hotel Business in Republic of Uzbekistan
}

\author{
Djumaev Bobir Askarovich ${ }^{1}$, Vladimir Anatolevich Rubtzov², Niyaz Minnahmatovich Biktimirov $\#$ \\ ${ }^{1}$ Postgraduate student of the Department of service and tourism of the Institute of management, Economics and Finance of the \\ Kazan Federal University, \\ Scopus ID no, ORCID ID 0000-0001-6324-3286 \\ ${ }^{2}$ Doctor of geographical Sciences, Professor, Department of service and tourism, Institute of management, Economics and
}

Finance, Kazan Federal University, Scopus ID 56333300100, ORCID ID 0000-0002-9918-9231

${ }^{3}$ Candidate of geographical Sciences, associate Professor, Department of service and tourism, Institute of management, Economics and Finance, Kazan Federal University, Scopus ID 56104332400, ORCID ID 0000-0001-8582-708X

\begin{abstract}
The article outlines the problems of the modern tourism hospitality industry and its component - the hotel industry, the development of which stimulates the development of other services sector.The tourist market of Uzbekistan is analyzed, data are provided on both the global growth of the hotel business and the development of hotel facilities in cities that have the prerequisites for the development of the tourism and hotel industry in the selected country. After the analysis, the problem of substantiating the effectiveness and development prospects of this area arises. The components of the huge potential for the development of tourism in Uzbekistan are shown, which played in the formulation of specific tasks for the leaders of this sphere in developing the National Tourism Development Concept for 2019-2025. The purpose of this article is to develop recommendations and suggestions on the development of tourism for the efficient functioning of hotels in the cities of Uzbekistan with developed tourist infrastructure. The article presents a model of organizational and economic support for the functioning of the hotel industry based on the study of tourist flow, and a model for predicting the effectiveness of the functioning of the hotel industry is developed. In particular, the forecast indicators necessary to increase the number of hotels with the development of the tourism sector in the Republic of Uzbekistan from 2018 to 2025 are presented.As a result of the study, recommendations on the development of the tourism and hotel industry are offered. Among which an important place is the creation of an integrated system of training professional personnel, improving the quality of education and the provision of services, meeting the demand for highly qualified personnel. The implementation of relevant recommendations and proposals will significantly develop the country's tourism infrastructure in the future and turn it into one of the profitable sectors of the economy.
\end{abstract}

Keywords: Hotel Industry, Competitiveness, Indexes of Competitiveness, Hotels of Uzbekistan, Tourism in Uzbekistan.

\section{BACKGROUND}

The hotel industry is one of the fastest growing economies, accounting for $6 \%$ of global GNP and about $5 \%$ of total tax payments. The development of the hotel industry stimulates other areas of activity, such as: transport, trade, construction, agriculture, production of consumer goods, the provision of various kinds of services.

Typically, for every ten travelers traveling in hotels, there are about 3 jobs directly and two jobs, indirectly. (employees of travel agencies, transport companies, etc.). World Hotel Fund is $17-18$ million beds, and this figure is constantly growing [9]. The hotel industry attracts entrepreneurs for several reasons: firstly: small start-up investments, growing demand for travel services, and secondly, a high level of profitability and, accordingly, an average payback period. Over the past 3 years, thanks to the increasing flow of tourists, the global hotel business is developing in a real way: hotel loading and living expenses have increased markedly, hotel companies have expanded their presence around the world.

\section{METHODOLOGY}

In the work, the methods of analysis and synthesis of scientific literature published in Russia and abroad were applied. General approaches tested during the study.

\section{RESULTS}

From 2016 to the present, Uzbekistan has seen an accelerated development of the entire tourism industry. By the Decree of the President of the Republic of Uzbekistan Sh.Mirziyoyev dated December 2, 2016, UP-4861 "On additional organizational measures to create favorable conditions for the development of the tourist potential of the Republic of Uzbekistan" defined targets and, in the medium term, one of the priority areas of public policy in the sphere of tourism and its targets tasks are defined as “... giving the status of a strategic sector of the economy to the tourism sector, turning 
this sector into a powerful tool for sustainable development, structural reobrazovany and diversification of the economy, which should become a driving force to accelerate the integrated development of all regions and related industries... ".

In the country in recent years, a number of benefits have been provided for travel companies or those who are going to do this. Exemption from part of the taxes, the allocation of land, long-term loans and much more. In this regard, the Decree of the President of the Republic of Uzbekistan dated 03.02.2018 No. UP-5326 "On additional organizational measures to create favorable conditions for the development of tourist potential in the Republic of Uzbekistan" was issued. It defines a number of benefits and preferences as exemption from customs payments (except for customs clearance fees) hotels and other accommodation facilities for up to January 1, 2022 for imported equipment, equipment, raw materials, components and spare parts, construction and other materials, reconstruction and equipment of theme parks, hotels and other accommodation facilities according to lists approved in the established manner [7].

In general, the State policy in the field of tourism is aimed at shaping the tourism industry in the locomotive of accelerated and integrated development of regions and their infrastructure, increasing jobs, ensuring diversification and accelerated development of regions, increasing incomes living standards improvement the image and investment attractiveness of the country in the international arena.
In this regard, in a message of the President of Uzbekistan Sh.Mirziyoyev to the Parliament of Oliy Majlis on December 28, 2018, the Head of State brought a number of priorities to bring economic reforms to a new, higher level. Having listed the eighth of priority directions which was "Development, attraction of investments in the sphere of tourism and increase of potential of the personnel of this sphere". He also stressed that often for many tourism in Uzbekistan is associated with our ancient cities, historical and cultural monuments. But the country has a great opportunity for tourism development

- our unique nature, national reserves, recreational zones in mountainous areas, and on this basis gave specific tasks to the leaders of this sphere about the development of the National concept of tourism development for 2019-2025. So that by 2025 the number of foreign tourists visiting the country annually was at least 7 million, and the income from the development of tourism exceeded 2 billion dollars.

The religious factor, together with the ethnic one, can have a significant impact on both socio-economic development of the territory [8]. Study allowed us to determine the significance of religious tourists, who are more careful about the choice of tourist services $[5 ; 6]$.

During 2000-2018 Modern hotels and many similar accommodation facilities have been built in Uzbekistan. According to the State Committee for the Development of Tourism of the Republic of Uzbekistan, by 2020, Uzbekistan plans to build 300 budget and branded hotels.

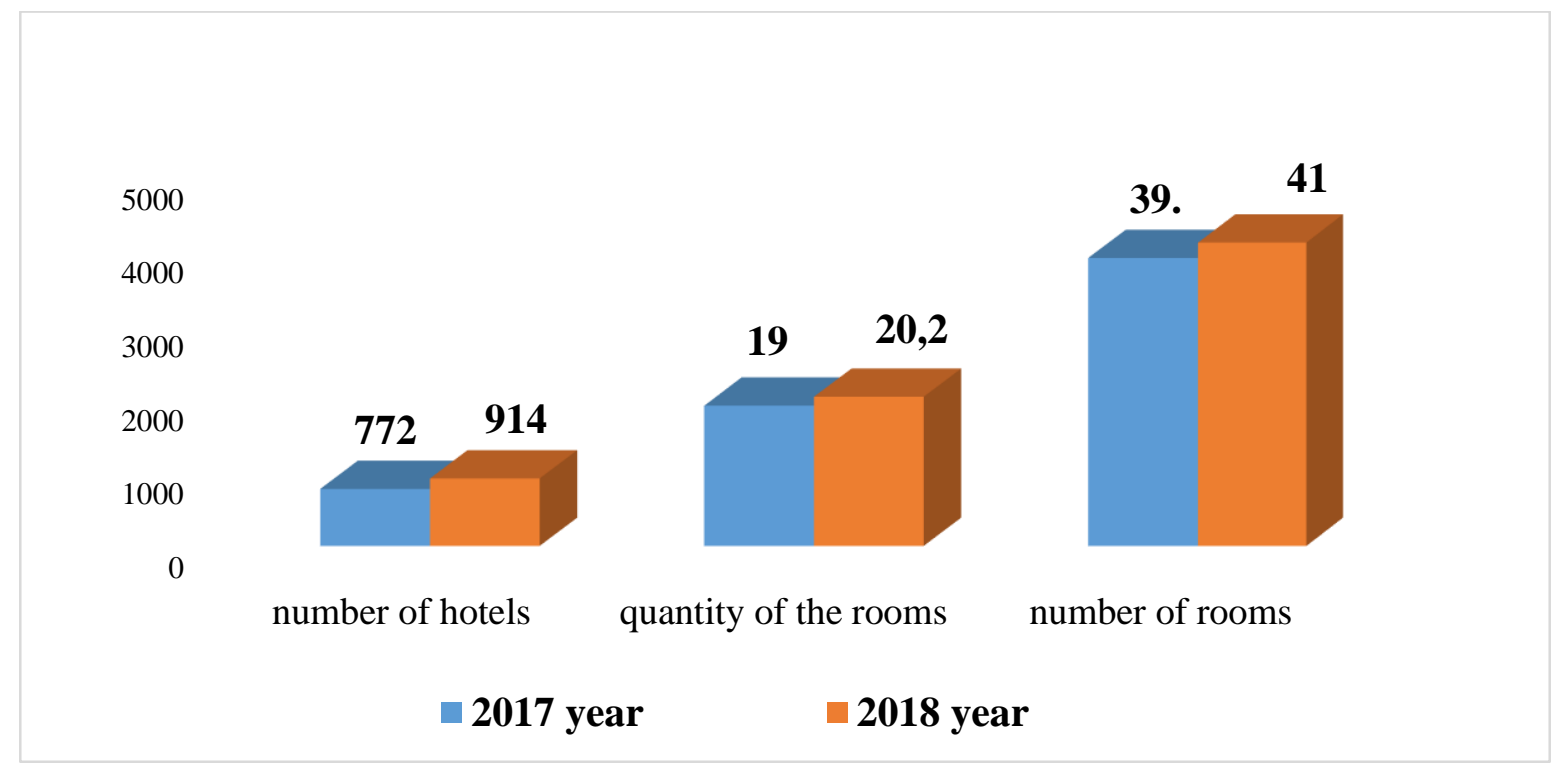

Fig. 1: Accommodation facilities

In 2017, the number of hotels and similar accommodation units was 772. By 2018, the number of hotels was 914, which is $16 \%$ more than the same period. The total number of rooms (rooms) in 2017 the number of hotel rooms was 19 thousand, and since 2018 this figure increased by 20.2 thousand, which is $6 \%$ more, and the number of beds in 2017 was 39 thousand, and in 2018 increased by $5 \%$ to 41 thousands of places (Fig. 1).
In the course of the implementation of State reforms in the country, the number of foreign visitors is growing. So, in 2017, 2,690 thousand foreign visitors entered the Republic of Uzbekistan. This figure is $32.7 \%$ more compared to 2016, when the number of arrivals was 2,027 thousand people. In turn, during 2018, the number of foreign visitors amounted to 5346 thousand people and exceeded the figures for the same period in 2017 by $99 \%$ (Fig.2). 


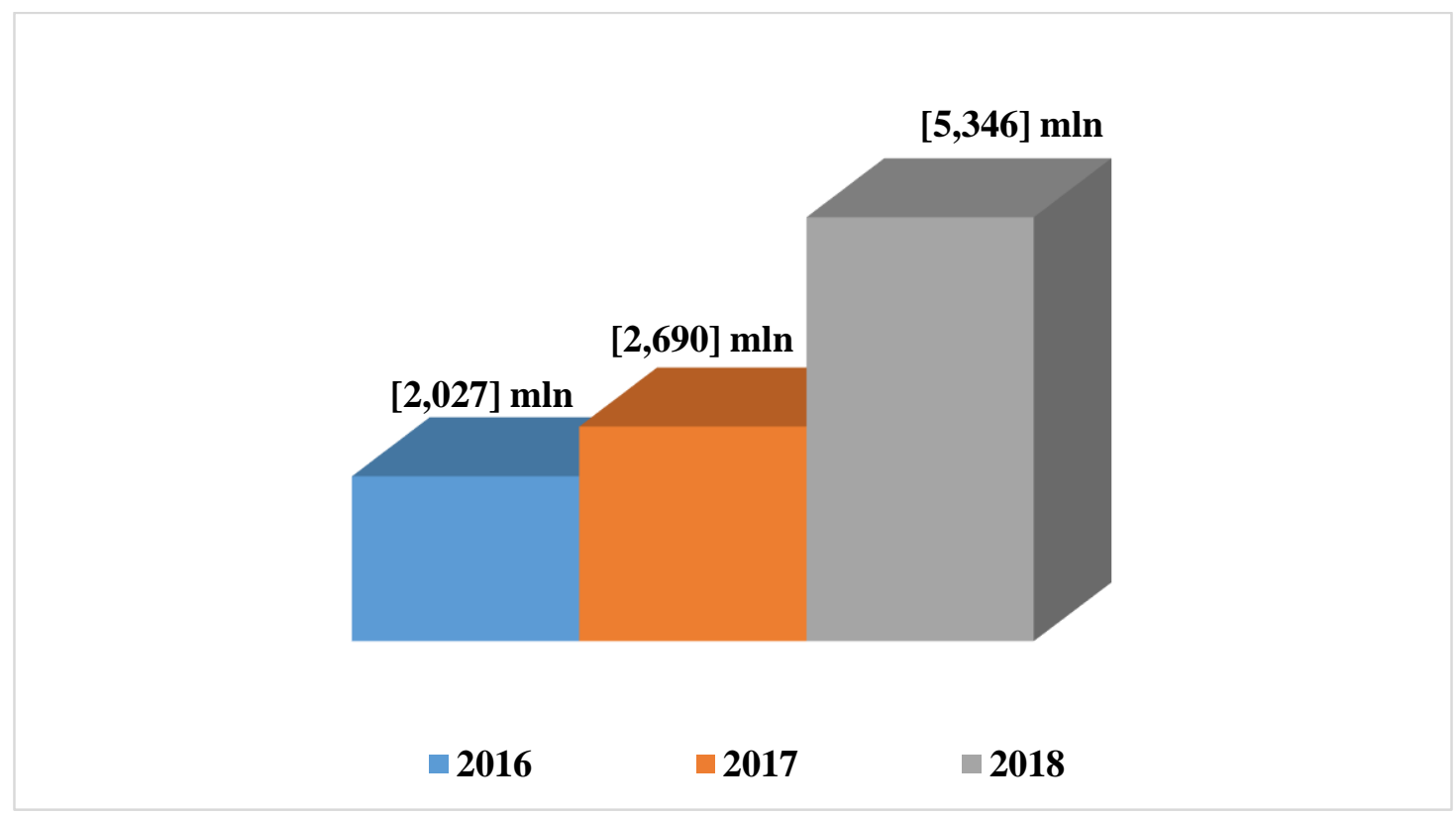

Fig.2: Number of arriving visitors (in million people

The largest part of the arrival of foreign visitors is in the month of August, the smallest - in February.

In general, for 2018 the main part of the flow of tourists is almost evenly distributed in March-December, when the number of visitors exceeded more than 400 thousand people per month. Low flux is observed in January-February (Fig.3).

If in 2018 the average for the month of visiting tourists was about 400 thousand, the average length of stay is 6-8 days, then during the month, hotels can accommodate no more than $50 \%$ of visitors. Therefore, there is a great need for organization and development of hotel facilities, serving in the month as a whole. 400-500 thousand tourists.

According to the State Committee for Tourism Development of the Republic of Uzbekistan, table 1 shows the projected these indicators represent the need to increase the number of hotels with the development of the tourism sector in the Republic of Uzbekistan from 2018 to 2025 [1; 2].

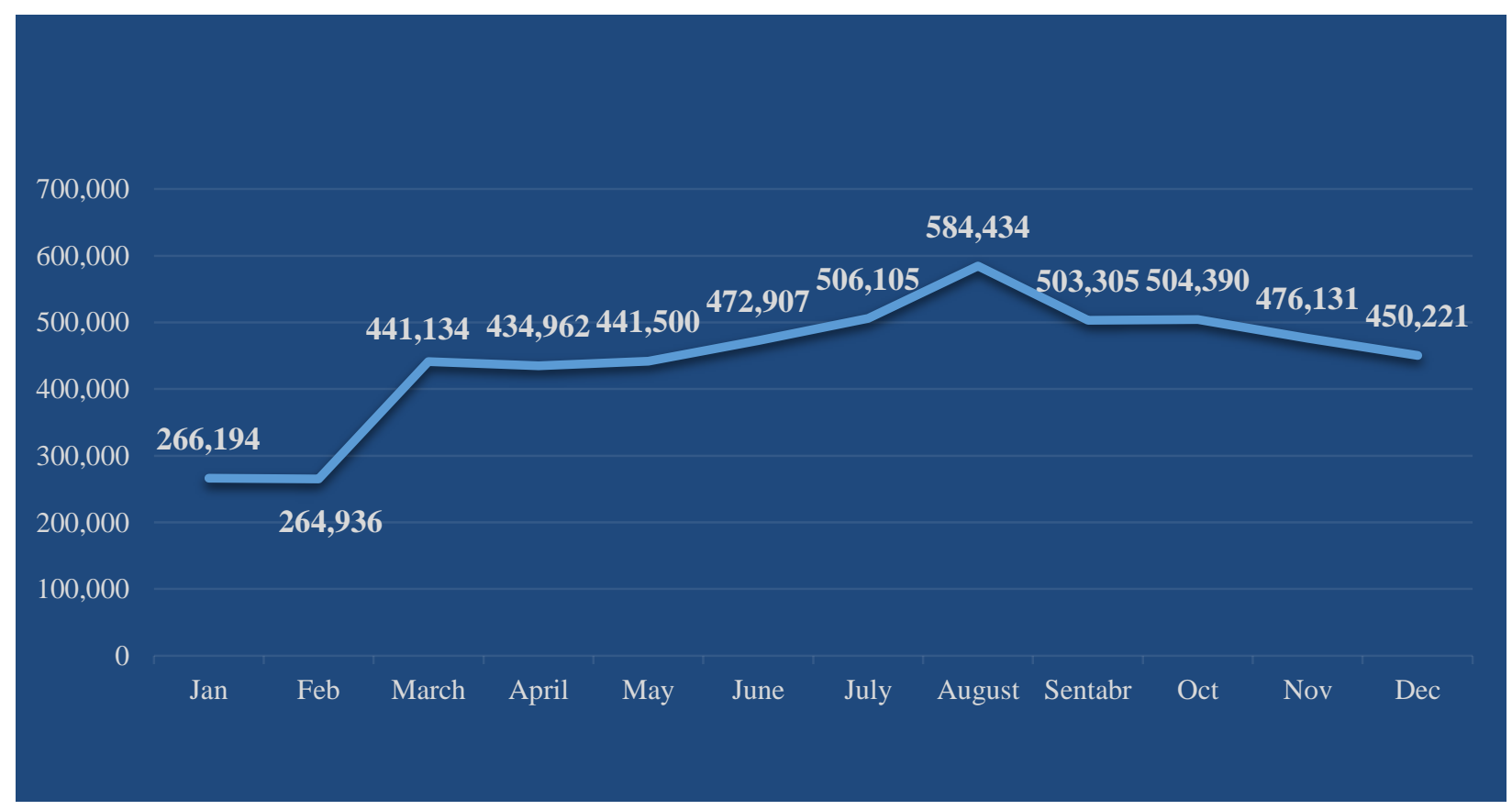

Fig.3: Distribution of the flow of visitors by months in thousands of people (for 2018) 
International Journal of Engineering Research and Technology. ISSN 0974-3154, Volume 13, Number 11 (2020), pp. 3654-3658

(C) International Research Publication House. https://dx.doi.org/10.37624/IJERT/13.11.2020.3654-3658

Table 1: Target indicators of development of the tourism industry of the Republic of Uzbekistan from 2018 to 2025

\begin{tabular}{|c|c|c|c|c|c|c|c|c|c|}
\hline № & Indexes & 2018 & 2019 & 2020 & 2021 & 2022 & 2023 & 2024 & 2025 \\
\hline 1. & $\begin{array}{l}\text { Number of } \\
\text { foreign of tourists visiting Uzb } \\
\text { (thousand people) }\end{array}$ & $\begin{array}{l}\text { ¿ } \\
\text { in }\end{array}$ & $\begin{array}{l}a \\
\infty \\
\infty \\
n\end{array}$ & 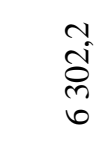 & $\frac{m}{\frac{m}{2}}$ & $\begin{array}{l}\infty \\
\text { N } \\
\text { N } \\
N\end{array}$ & $\begin{array}{l}v^{\prime} \\
i \\
\infty \\
\infty\end{array}$ & 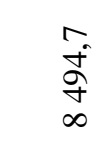 & $\begin{array}{l}m \\
\infty \\
0 \\
0\end{array}$ \\
\hline 2. & $\begin{array}{l}\text { Count about the lounge. } \\
\text { and analog. funds } \\
\text { posting (unit) }\end{array}$ & $\frac{\Delta}{a}$ & $\stackrel{\infty}{\stackrel{8}{0}}$ & 8 & $\begin{array}{l}\text { ते } \\
\text { ते }\end{array}$ & $\begin{array}{l}\text { రె } \\
\text { ֶे }\end{array}$ & $\frac{n}{\sqrt{N}}$ & $\begin{array}{l}\bar{\sim} \\
\text { ते }\end{array}$ & ন্ \\
\hline 3. & $\begin{array}{l}\text { Number of rooms } \\
\text { in the funds posted. } \\
\text { (thous.) }\end{array}$ & 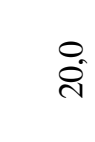 & $\stackrel{\sim}{\sim}$ & $\vec{m}$ & $\stackrel{\hat{D}^{\circ}}{ }$ & त̂ & ñ & $\begin{array}{c}0 \\
\infty \\
\infty\end{array}$ & $\ddot{8}$ \\
\hline 4. & $\begin{array}{l}\text { Number of places } \\
\text { in the funds posted. (thous.) }\end{array}$ & $\stackrel{F}{\nexists}$ & กิ & in & है & $\stackrel{m}{\beth}$ & $\overline{\tilde{g}}$ & 气ิ & $\stackrel{\vec{v}}{\stackrel{\sim}{2}}$ \\
\hline
\end{tabular}

Note: The data provided from the State Committee of the Republic of Uzbekistan for the development of tourism.

\section{SUMMARY}

One of the determining factors in planning and forecasting tourism activities is tourist motivation. It is on it that the creation and implementation of the tourism product should be built today [10].

Established forms of human being find appropriate expression in work, interests, opinions that are most directly reflected in the tourist choice of a person [3].

Proceeding from the requirement to achieve economic profitability in the foreign trade balance and in the provision of international services, the state tourism policy should be aimed at improving the efficient operation of hotel services, which is one of the main parts of this area about the need to increase the number of hotels in Uzbekistan from 2018 to 2025 from 914 to at least 2994, the number of rooms from 20 thousand to 60.9 thousand and the number of places from 41.1 thousand to 132.4 thousand, which should be about 3 times os for the development of healthy competition in the hotel industry in the country. And in a healthy competitive environment, in turn, new innovative ideas will be implemented and new technologies will be introduced [4].

\section{DISSCUSSION AND CONCLUSION}

Targets in this direction are:increasing the attractiveness of the tours offered by saturating their event activities and combining various types of tourism, an increase in the average duration of tours in the country for at least two days, bringing up to 8 days, and in cities for 3 days from the current 1.5-2.0; ensuring sustainable development of tourism and achieving repeat visits of visitors to the country.
1) the development of domestic tourism, providing incentives for the activity of subjects of tourist activity oriented to meet the needs for tourist services within the country.

The task in this direction:effectively use internal resources to form a high-quality tourist product, reduce dependence on seasonal factors and increase the workload of hotels, especially in non-seasonal months of the year;to expand the flow of domestic tourists between the regions with an increase in their number from 14 million to 25 million per year.

2)promotion of the tourist product of the Republic of Uzbekistan in the domestic and foreign tourist markets, strengthening the country's image as safe for travel and recreation.

It is necessary to form an image of a country with a developed tourist industry and a rich tourist potential, as well as a safe for travel and leisure, to ensure the development of new potential markets, to increase the number of foreign visitors from 5.3 million to 9.1 million people a year, as well as foreign partners to attract tourists to Uzbekistan

3) improvement of the system of training highly qualified specialists, retraining and advanced training of employees providing services.

It is envisaged to create an integrated system of training professional personnel, to improve the quality of education and the provision of services, to satisfy the demand for highly qualified managers, administrators, operators, porters of cooks. 


\section{ACKNOWLEDGEMENTS}

The work was performed within the framework of the Program of the Government of the Russian Federation on the development of competitiveness of the Kazan Federal University.

\section{REFERENCES}

[1] Baxtishodovich, B. S., Suyunovich, T. I., \& Kholiqulov, A. The start-up of tourism in Central Asia Case of. World Scientific News. 2017.

[2] Bobur, S., \& Alimova, M. Systematic approach to the development of innovative tourism. Case of Uzbekistan regions. South Asian Journal of Marketing \& Management Research, 2017.

[3] Bunakov, O.A. Development of tourism in the region on the basis of cluster approach. International Business Management, 2016, 10(21), pp. 5104-5106.

[4] Dzhumaev, B., Rubtsov, V. The cluster approach in the tourism industry. International Youth Symposium on Management of Economics and Finance, IUEiF, KFU, Kazan, 2019, 28-29, pp. 484-487.

[5] Gabdrakhmanov, N.K, Biktimirov, N.M, Rozhko, M.V, Mardanshina, R.M. Features of islamic tourism. Academy of Marketing Studies Journal, 2016, 20, pp. 45-50.

[6] Gabdrakhmanov, N.K, Biktimirov, N.M, Rozhko, M.V. Problems of development of halal tourism in Russia. Journal of Organizational Culture, Communications and Conflict, 2016, 20(2), pp. 88-93.

[7] Mousavi, S.Z., Jalilinasrabady, S., Ghalamghash, J. Touristic Potential of Meshkinshahr Geothermal Resources. NW Iran. In World Geothermal Congress, 2015,- pp. 9.

[8] Rubtzov, V.A., Rozhko, M.V., Gabdrakhmanov, N.K., Gilmanova, A.A. Competitiveness and positioning of municipalities in the Republic of Tatarstan. Mediterranean Journal of Social Sciences, 2015, 6(3), pp. $761-765$.

[9] Zambinova, G.K., Bekisheva, S.T. Assessment of tourist-recreational resources of Kazakhstan. Научный Результат. Серия «Технологии Бизнеса и Сервиса» 2015, pp. 4.

[10] Zinovyeva, A.A.,Shabalina, S.A. Human resources in management of smoothing of geographical space polarization of the region. Amazoniai nvestiga.-. - Том 7. Вылуск, 2018, 15, pp. 81-87.

\section{Djumaev Bobir Askarovich}

In 2007-2013, he studied at the Samarkand State University at the faculty of management of Economics in the Republic of Uzbekistan. From 2013 to 2019, he worked as a teacher at the Samarkand Institute of Economics and service. Since 2020, he has been a post-graduate student at the Department of service and tourism of the Institute of management of Economics and Finance at the KFU. Topic of the research and qualification work: "Spatial aspects of tourism organization based on the cluster approach on the example of the Republic of Uzbekistan". Also, the area of research interests is fundamental Economics, financial system, management of tourist enterprises.

\section{Rubtzov Vladimir Anatolevich}

1975-1980 studied at Kazan state University in the faculty of applied mathematics and Cybernetics.Qualification: mathematician. Professor of the Department of service and tourism, doctor of geographical Sciences. Research interests: theoretical and methodological problems of social, recreational and economic geography, forecasting, zoning, mathematical methods and modeling of geography, tourism and the hospitality industry, stability, balance of territorial socio-economic systems. Author of more than 300 works.

\section{Biktimirov Niyaz Minnahmatovich}

In 1997-2002, he studied at the Kazan state pedagogical University as a teacher of geography and biology. After graduating from the University with honors, he studied in a postgraduate course in "economic geography". In 2016, at Perm state University, he defended his PhD thesis on "Ethnic aspects of geodemographic development of the population of the Republic of Tatarstan in the XXI century". Specializes in demography, demography, migration and regional tourism. Today he is an associate Professor of the Department of service and tourism of KFU. The list of published works is more than 150 . 